\title{
Development of Connective Tissue Fibres in Pancreas of Prenatal Stages of Goat (Capra hircus)
}

\author{
Dharmendra Singh $^{1 *}$, Ajay Prakash ${ }^{1}$, M.M. Farooqui ${ }^{1}$, \\ Sri Prakash Singh ${ }^{1}$ and Avnish Kumar Gautam ${ }^{2}$ \\ ${ }^{1}$ WBUAFS Kolkata-37, DUVASU Mathura, India \\ ${ }^{2}$ Veterinary Anatomy, Bihar Veterinary College, Patna-14, India \\ College of Veterinary Science and Animal Husbandry (DUVASU), Mathura-281001, India
}

*Corresponding author

\section{A B S T R A C T}

\begin{tabular}{|l|}
\hline Ke y w or d s \\
Connective tissue \\
fibers, Pancreas, \\
Prenatal goat
\end{tabular}

The present study was conducted on the 24 goat foeti of either sex ranging from 42 days to full term of gestation. The material was divided into early prenatal ( 0 to 50 days), mid prenatal (51 to 100 days) and late prenatal (101 to till term) periods. In all goat foetuses the pancreas lied in the abdominal cavity partly on right and partly on left side of median plane. Tissue processing was done with routine histological technique. Up to 59 days gestation the reticular fibers, collagen fibers and elastic fibers were absent in foetal goat pancreas. Fine reticular fibers along with fibroblasts were first observed at 69 days of gestation. From 76 days onwards reticular fibers and fibroblast were more pronounced in capsule, interlobar and interlobular areas. Moreover, these encircled the tubules, buds, acini, islets and blood vessels. Beyond this the reticular fibres gradually became coarser with the increase in age of foetus. Fine collagen fibres having a little bluish tinge were seen around vicinity of blood vessels at 115 days and distinct fine collagen fibres were observed at 118 days of gestation. No elastic fibres were observed at any stages of prenatal goat.

\section{Introduction}

The Pancreas is a tubuloalveolar gland comprises exocrine and endocrine tissues. The exocrine portion of pancreas which contributes $95 \%$ of pancreatic mass secretes digestive enzymes into the duodenum and it includes acinar and duct cells with associated connective tissue, vessels and nerves. The endocrine portion of pancreas contributes 1$2 \%$ of pancreatic mass and it synthesizes insulin, glucagon and somatostatin and pancreatic polypeptide (Balasundaram, 2018). The connective tissue fibres viz. collagen fibres, reticular fibres and elastic fibers play important role in support to the parenchymatous tissues of pancreas. On perusal of literature it has been observed that little attention has been paid towards study of the pancreas especially during the prenatal period of goat. Therefore, the present study has been undertaken to reveal the development of connective tissue fibres in pancreas of prenatal goat. 


\section{Materials and Methods}

The present study was conducted on the pancreas of 24 foeti procured from healthy goats (caprahircus) of non descript breed. Immediately, after collection each foeti was measured for its crown rump length (CRL) in centimeters with the help of nylon tape as per the technique described by Harvey (1959). The approximate age of foeti was estimated by using the formula derived by Singh et al., (1979) in goat after interpolation of formula of Hugget and Widdas (1951) in mammals. The foeti were divided into three groups on the basis increasing gestational age (Table 1). For histological studies, the tissue samples were collected from all the foetuses and fixed in 10 percent Neutral Buffered Formalin. The fixed tissues were processed through alcoholbenzene- paraffin embedding technique and 5$6 \mu \mathrm{m}$ thick sections were obtained. The sections were stained with Wilder's reticular stain for reticular fibers, Masson's trichrome stain for collagen fibersand Verhoeff's stain for elastic fibers (Luna, 1968).

\section{Results and Discussion}

At 42 to 44 fetal days of early prenatal period the primordium of pancreas in goat was found in close vicinity of the developing duodenum and abomasum. In few sections it was almost in apposition to the wall of the duodenum to which it was connected by the developing mesentry. Singh and Sethi (2012)reported that the pancreas of buffalo foetus at 47 days gestation was suspended in a thin sheet in mesentery between liver and duodenum. The reticular, collagen and elastic fibers were absent in the goat pancreas in early prenatal period. By 59 days of gestation the collagen, reticular and elastic fibers were not found in the mesenchyme of foetal goat pancreas. However, the sporadic accumulation of argyrophilic elongated cells was observed in the peripheral part of mesenchymal tissue at
59 days gestation. However, Conklin (1962) in man found that in the beginning of foetal period at $30 \mathrm{~mm} \mathrm{CR}$ the pancreatic tubules were enclosed by acidophilic connective tissue fibers and sparse intertubuler stromal fibers were argyrophilic.

At 69 days gestation the stroma of developing goat pancreas consisted of numerous fibroblasts and mesenchymal cells along with fine reticular fibers and several congested blood vessels. At this stage the fibroblasts were usually present in more than one layer in the peripheral part of the stromal tissue whereas, at other places these were scattered either single or in groups. In the vicinity of the tubules, buds and developing islets the fibroblasts were arranged either in the single layer or more than one concentric layer which partially or fully encircled these structures. The reticular fibers were in almost complete thin layer around the developing pancreatic mass and formed partial or complete circularly dispersed sparse network around the tubules, buds and developing islets of Langerhans. The network of fine reticular fibers was also observed between the parenchymal patches. The collagen and elastic fibers were absent at this stage (Fig. 1). At 11 to 12.5 weeks gestation in fetal pancreas of man loose stroma of argyrophilic fibers were found between tubules (Conklin, 1962). In 76 day old goat fetal pancreas thin reticular fibers encircled the individual tubule and bud and also around the groups of tubules and buds into small compartments. The intertubular fibers remain reticular until end of third month of gestation in man (Conklin, 1962). Beyond 76 day gestation in all the stages of mid prenatal period the fibroblasts and reticular fibers gradually became more pronounced in the stromal tissue including interlobular and intra lobular areas. In the late stages of mid prenatal period dense layers of fibroblasts along with relatively coarser reticular fibers were observed in the capsule. 
The distinct collagen fibers were absent in different stages of mid prenatal period, however, from 87 days gestation very fine fibers having a little bluish tinge were found in the stromal tissue which were generally more pronounced in the vicinity of the blood vessels. Conklin (1962) in the foetal pancreas of man reported that the reticular fibers were the predominant fibers type until about the eighteenth week of gestation when the fibers which enclosed the parenchymal elements acquired the staining characteristics of collagen fibers. However, Singh and Sethi (2012) in buffalo found that at 138 days of gestation collagen and reticular fibers were well differentiated in the connective tissue surrounding the acini. The elastic fibers were absent in the foetal pancreas of goat.

Table.1 Showing the number of goat foeti with their calculated age groups

\begin{tabular}{|l|c|c|c|}
\hline \multicolumn{2}{|c|}{ Groups } & $\begin{array}{c}\text { No. of experimental units/ } \\
\text { foeti }\end{array}$ & Age groups \\
\hline $\begin{array}{l}\text { I. Early } \\
\text { period }\end{array}$ & prenatal & 6 & 0 days - 50 days \\
\hline $\begin{array}{l}\text { II. Mid } \\
\text { period }\end{array}$ & prenatal & 10 & 51 days - 100 days \\
\hline $\begin{array}{l}\text { III. Late prenatal } \\
\text { period }\end{array}$ & 8 & $\begin{array}{c}101 \text { days - till full } \\
\text { parturition days of } \\
\text { gestation }\end{array}$ \\
\hline
\end{tabular}

Fig.1 Section of 69 days old goat foetal pancreas showing fine reticular fibers in capsule (A) around tubule (B)

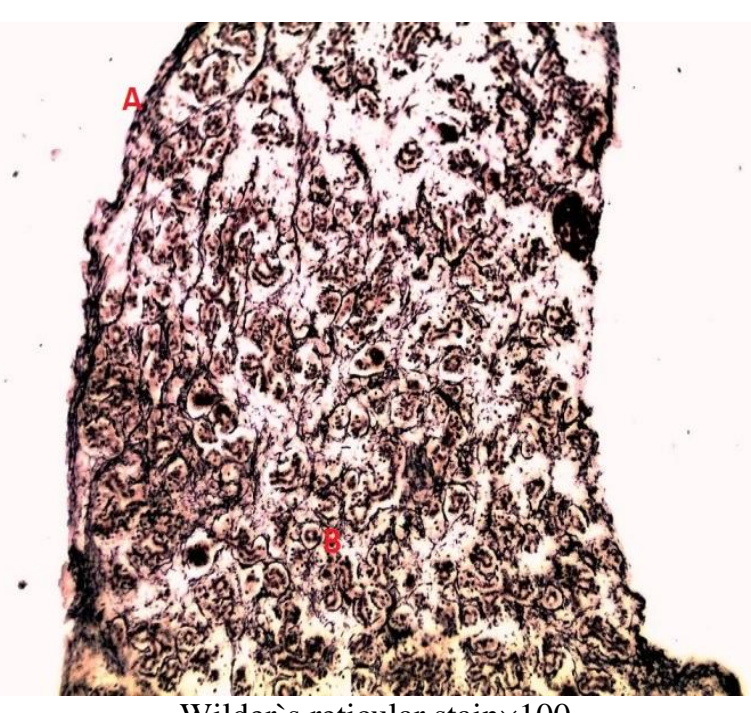

Wilder`s reticular stain $\times 100$ 
Fig.2 Section of 101 days old goat foetal pancreas showing reticular fibers around acini (A)

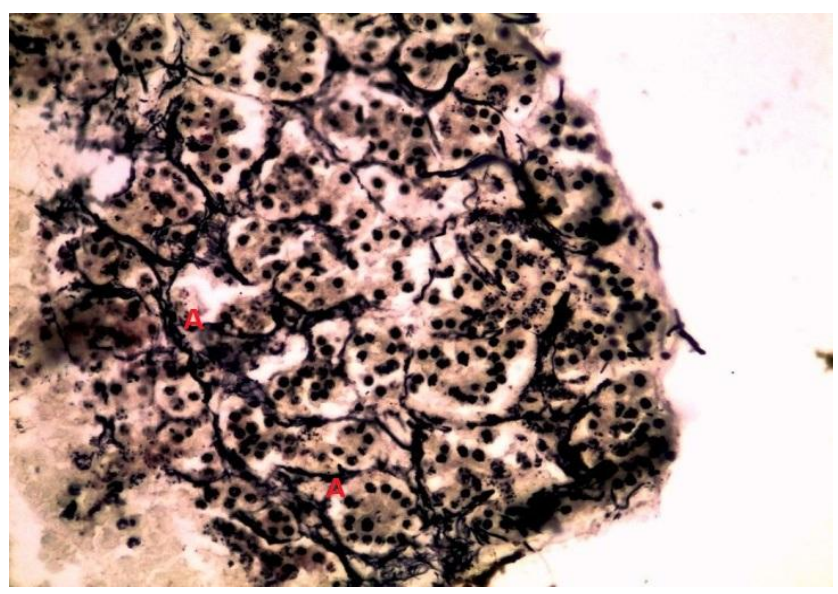

Wilder`s reticular stain $\times 400$

Fig.3 Section of 115 days old goat foetal pancreas showing reticular fibers in capsule (A), around developing acini (B) and around developed acini (C)

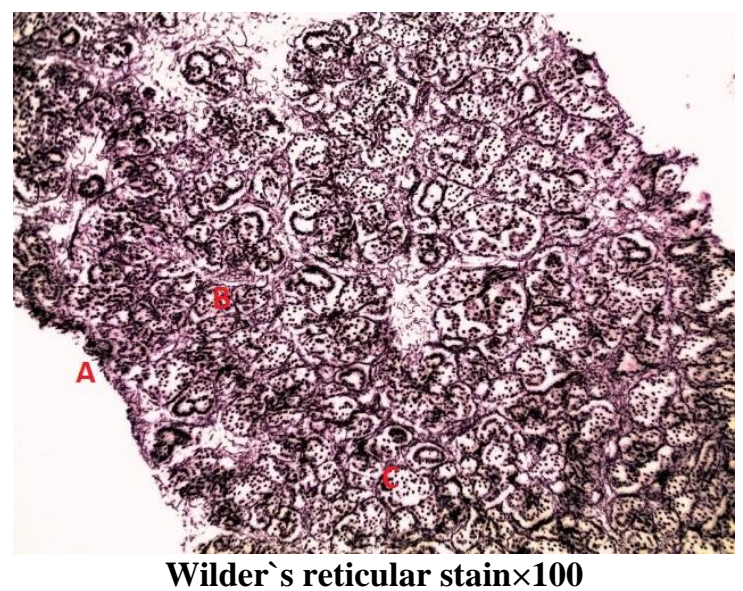

Fig.4 Section of 115 days old goat foetal pancreas showing fine collagen fibers around acini (A)

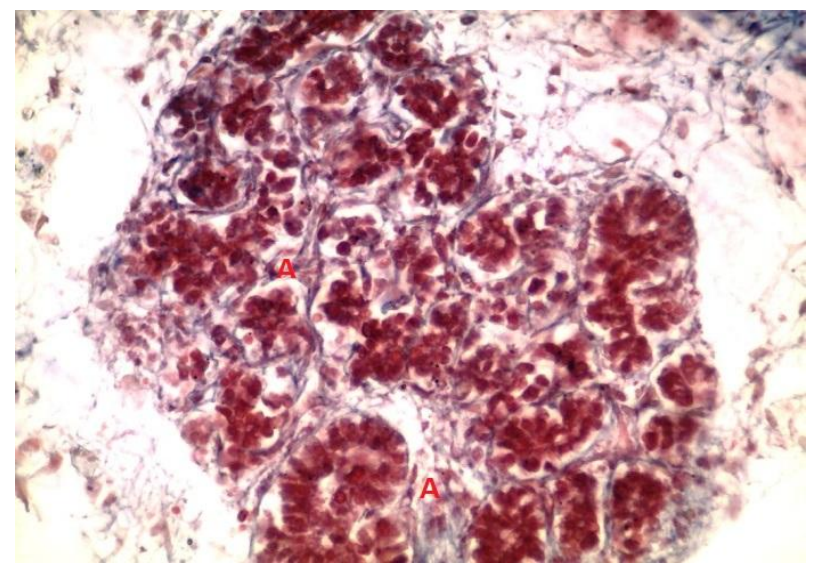

Masson`s trichome stain $\times 400$ 
Fig.5 Section of 118 days old goat foetal pancreas showing collagen fibers around acini (A) and blood vessel (B)

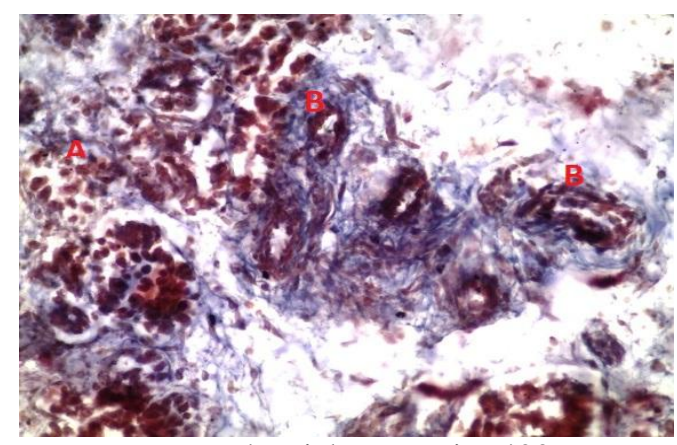

Masson`s trichome stain $\times 400$

In late prenatal period, at 101 days gestation the stroma of developing goat pancreas had fine to coarse reticular fibers around the acini, numerous fibroblasts and few mesenchymal cells along with congested blood vessels (Fig. 2). The reticular fibers gradually became coarser in the stromal tissue of capsule, interlobular and intralobular septa, around the acini and islets of Langerhans with increase of the foetal age from 103 to 132 days gestation(Fig. 3). Distinct collagen fibers were not found up to 115 days gestation of late prenatal period. However, very fine collagen fibres having a little bluish tinge were seen around the acini (Fig. 4). At 118 days gestation the parenchyma of foetal goat pancreas was surrounded by a distinct capsule which had relatively coarser reticular fibers, fine collagen fibers and numerous fibroblasts. The septae consisted of fine to coarser reticular fibers, few fine collagen fibers and fibroblasts along with numerous free erythrocytes. By 118 days of gestation collagen fibers were distinctly observed around the acini and blood vessel (Fig. 5). Sujatha et al., (2012) in the pancreas of human foetus observed that the acini were arranged into group separated by connective tissue at the age of 28 to 30 weeks. According to Gupta et al., (2002) in the foetal pancreas of man between 24.1 to 30 weeks gestation the interlobular connective tissue was well differentiated.

\section{References}

Harvey,E.B., 1959. Ageing and foetal Development. In Reproduction in domestic Animals. (Eds.) H. Cole and P.T. Eupps. $1^{\text {st }}$ edn., Vol. I Academic Press Inc., New York.

Balasundaram, K., 2018.Histomorphology of pancreas in Goats. Journal of pharmacognosy and Phytochemistry. SPI:1711-1713.

Conklin J. A., 1962. Cytogenesis of the human fetal pancreas. American Journal of Anatomy.1962; 111: 181193.

Gupta V., Garg K., Raheja S., Chaudhry R. and Tuli A., 2002. The histogenesis of islets in the human foetal pancreas. $\mathbf{J}$ Anat. Soc. India 51 (1): 23-26, 2002.

Harvey, E. B., 1959. Ageing and foetal Development. In Reproduction in domestic Animals. (Eds.) H. Cole and P.T.Eupps. $1^{\text {st }}$ edn., Vol. I Academic Press Inc., New York.

Hugget A. St. G. and Widdas, W.F.,1951. The relationship between mammalian foetal and conception age. Journal of Physiology, 114: 306-317.

Luna L. G., 1968.Manual of histological staining methods of armed forces institute of pathology. $3^{\text {rd }}$ edn. The blakistan Division Mc-Graw Hill 
Book Company, New Yark.

Singh O. and Sethi R.H., 2012. Histogenesis of pancreas of Indian buffalo (Bubalus bubalis) during prenatal development. Indian Vet. J. 89 (11): 56-59, November, 2012.

Singh, Y., Sharma, D.N and Dhingra, L.D., 1979. Morphogenesis of testes in goat.
Indian J Ani Sc, 49(11): 925-931. Sujatha M., Sugavasi R., Devi I.V., SirishaB., Devi S.V. and Suneetha Y., 2012. Morphometry and histogenesis of human foetal pancreas. International journal of health science and research, December issue.

\section{How to cite this article:}

Dharmendra Singh, Ajay Prakash, M.M. Farooqui, Sri Prakash Singh and Avnish Kumar Gautam. 2018. Development of Connective Tissue Fibres in Pancreas of Prenatal Stages of Goat (Capra hircus). Int.J.Curr.Microbiol.App.Sci. 7(07): 2878-2883.

doi: https://doi.org/10.20546/ijcmas.2018.707.337 